\title{
Petrography and Chemistry of the Jericho kimberlite (Slave Craton, Northern Canada)
}

\author{
Kopylova, M. G. ${ }^{1}$, Russell, J. K. ${ }^{1}$, Cookenboo, H. ${ }^{2}$ \\ 1. Geological Sciences Division, Department of Earth and Ocean Science, The University of British Columbia, \\ Vancouver, Canada, V6T 1Z4 \\ 2. Canamera Geological Ltd., 399 Mountain Highway, North Vancouver, Canada, V7J 2K9
}

The Middle Jurassic (172 Ma, Heaman et al., 1997) Jericho kimberlite is located $400 \mathrm{~km}$ northeast of Yellowknife and $3 \mathrm{~km}$ north of Contwoyto Lake. Mineralogically the Jericho kimberlite is a typical non-micaceous kimberlite lacking groundmass tetraferriphlogopite (Mitchell, 1995). Chemically, based on $\mathrm{TiO}_{2}, \mathrm{~K}_{2} \mathrm{O}, \mathrm{Pb}$ and $\mathrm{SiO}_{2}$ abundances, the Jericho kimberlite is classified as Group Ia.

Based on logging of drill core the Jericho kimberlite has been subdivided into 3 distinct phases. The phases are numbered in terms of their relative ages. The earliest phase (Phase 1) is hypabyssal kimberlite that forms a precursor dyke and occurs as autholiths in later phases of kimberlite; Phases 2 and 3 formed later in two diatremes (Cookenboo, this volume). Each facies comprises kimberlite that is petrographically and chemically distinctive (Table 1). These petrological variations represent 3 distinct magmatic events that record the chemical evolution of the Jericho magma.

Phase 1 kimberlite is a hypabyssal, macrocrystal, calcite serpentine kimberlite characterized by olivine, phlogopite, ilmenite, pyroxene and garnet macrocrysts. The groundmass is a mesostasis of anhedral calcite and serpentine enclosing euhedral olivine and spinel microphenocrysts, euhedral skeletal apatite, laths of phlogopite, and euhedral spinel, perovskite and ilmenite. Typically phlogopite shows Ba enrichment towards the rims. Aphanitic chilled margins of Phase 1 kimberlite demonstrate a groundmass enriched in olivine microphenocrysts, apatite, Ba-phlogopite, and opaques (Spl, Ilm, Per). Phase 1 kimberlite hosts calcite segregations of globular and irregular shape, rare autoliths of aphanitic micaceous kimberlite and autoliths of macrocrystal serpentine calcite kimberlite. The latter is characterized by low modal abundances of macrocrysts and oval concave segregations of calcite.

Phase 2 and Phase 3 comprise macrocrystal, serpentine kimberlite which may have formed in a lower part of the diatreme. In Phase 2 kimberlite, completely serpentenized macrocrysts are set in matrix composed of serpentine, secondary carbonate and opaques. Phase 3 kimberlite is characterized by fresh macrocrysts in a matrix of serpentine, opaques, late, euhedral, rhombic, zoned carbonate and mixed-layer Mg-rich clay mineral. A diatreme-facies affinity for these kimberlites is supported by the presence of pelletal lapilli and microlitic, radially-oriented $\mathrm{Ca}-\mathrm{Mg}$ inosilicate (clinopyroxene? actinolite?) on the outer surfaces of macrocrysts, and the absence of primary carbonate (Scott Smith, 1996). Phase 2 and Phase 3 kimberlites contain autoliths of hypabyssal kimberlite which is identical to Phase 1 kimberlite except for elevated modes of primary carbonate.

Selective sampling for geochemical studies provided fresh specimens uncontaminated by crustal xenoliths and ilmenite megacrysts; the Crustal Contamination Index is less than 1.25 and the Ilmenite Contamination Index is equal to $0.21-0.32$. Based on whole rock chemical compositions, the Jericho kimberlite appears relatively reduced; $\mathrm{Fe}_{2} \mathrm{O}_{3} / \mathrm{FeO}$ ratio $\approx 0.5$, which is lower than in South and West African kimberlites. Chemical compositions of Jericho kimberlite show strong positive linear correlations between $\mathrm{CaO}$ and $\mathrm{CO}_{2}$, and between $\mathrm{Zr}$ and $\mathrm{Nb}$ (Fig. 1). The low $\mathrm{Zr}$ concentrations found in Jericho kimberlite are unusual for an average Group I kimberlite. The high $\mathrm{Nb} / \mathrm{Zr}$ ratio seen in Jericho rocks is characteristic of the magma and is reminiscent of some micaceous Australian kimberlites (Fig. 1).

The Jericho facies are distinguished by $\mathrm{P}_{2} \mathrm{O}_{5}-\mathrm{K}_{2} \mathrm{O}$ contents (Fig.2). Hypabyssal kimberlite of Phase 1 and autoliths in Phase 2 and 3 contains the highest amount of $\mathrm{P}_{2} \mathrm{O}_{5}$; Phase 2 and 3 kimberlites are discriminated by low $\mathrm{P}_{2} \mathrm{O}_{5}$ values. The autoliths are almost chemically identical to Phase 1 kimberlite, but differ in higher $\mathrm{Ca}$ and $\mathrm{CO}_{2}$ contents. Phase 2 kimberlite is the most altered and serpentenized. It is differentiated by high concentrations of $\mathrm{K}_{2} \mathrm{O}$ and $\mathrm{Al}_{2} \mathrm{O}_{3}$ which are accommodated by secondary serpentine, chlorite and clay minerals, lower $\mathrm{MgO}$, higher $\mathrm{Fe}_{2} \mathrm{O}_{3} / \mathrm{FeO}$ ratios, $\mathrm{SiO}_{2}$ and water abundances. 
The chemical evolution of the Jericho magma is recorded via the 3 separate magmatic events that led to the formation of the pipe. A temporal and chemically continuous trend leads from high- $\mathrm{Nb}$ high-Zr Jericho magmas to magmas depleted in these elements (Fig.1). The trend begins with chilled margins of hypabyssal facies unique in high $\mathrm{Nb}$ and $\mathrm{Zr}$, continues to more fractionated early hypabyssal kimberlite found in Phase 1 and in autoliths, then to later Phase 2, and concludes with the latest Phase 3 kimberlite.

The Jericho magma was initially enriched in volatiles $\left(\mathrm{CO}_{2}, \mathrm{P}_{2} \mathrm{O}_{5}\right)$ and incompatible elements which are commonly concentrated in mafic alkaline magmas. The earliest magma as recorded by the chilled margins and kimberlite autoliths had elevated $\mathrm{Ba}, \mathrm{Sr}, \mathrm{Nb}, \mathrm{P}, \mathrm{Zr}, \mathrm{Cr}, \mathrm{Ca}$ and $\mathrm{C}$ concentrations (Table 1). The hypabyssal precursor dyke (Phase 1) crystallized with similar chemistry, except with a lower $\mathrm{Ca}$ and $\mathrm{C}$ reflecting a lower proportion of primary calcite. Subsequent magmatic events let volatiles escape and formed chemically depleted kimberlites that are more fragmental in appearance and that occupy the lower part of the diatreme zone. The first diatreme was filled with a de-gassed magma that unferwent extensive serpentinization (reflected in loss of $\mathrm{MgO}$ and increase in $\mathrm{H}_{2} \mathrm{O}$ ) due to interaction with late magmatic hydrous fluids. The formation of the second diatreme from even more chemically depleted magma was accompanied by less severe auto-magmatic serpentinization.

Fig. 1

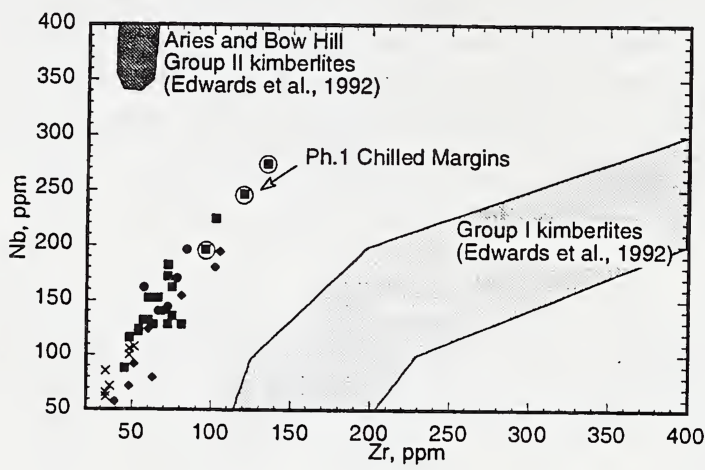

Fig. 2

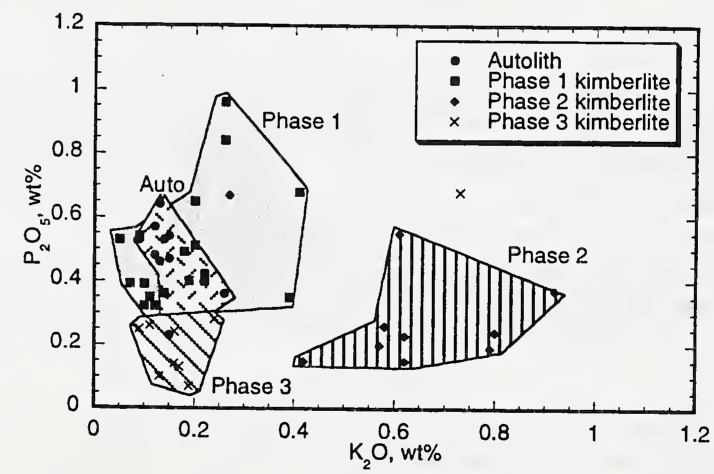

\section{References:}

Cookenboo, H., 1998. Emplacement history of the Jericho kimberlite northwest of Contwoyto Lake, NWT. In: Extended Abstracts, 7th Intern. Kimberlite Conf.

Edwards, D., Rock, N. M. S., Taylor, W. R., Griffin, B. J., and Ramsay, R.R., 1992. Mineralogy and petrology of the Aries diamondiferous kimberlite pipe, central Kimberley Block, Western Australia. Journal of Petrology. 33; 5: 1157-1191

Heaman L.M., Kjarsgaard B., Creaser R.A., Cookenboo H.O., and Kretschmar, 1997. Multiple episodes of kimberlite magmatism in the Slave Province, North America. In: Cook F. and Erdmer (compilers) Slave-Northern Cordillera Lithospheric Evolution (SNORCLE) transect and Cordilleran Tectonics Workshop Meeting (March 79), Univ. of Calgary, LITHOPROBE Report No. 56, 14-17

Mitchell, R.H., 1995. Kimberlites, orangeites, and related rocks. Plenum Press, New York, 410 p.

Scott Smith, B., 1996. Kimberlites. in: R.H. Mitchell (Ed.) Undersaturated alkaline rocks: mineralogy, petrogenesis, and economic potential. Mineralogical Assoc. of Canada, Short Course V. 24, 217-244 
Table 1. Bulk chemistry of Jericho kimberlite

Phase 1 $\mid \mathrm{Ph} 1$ Chilled margin $\mid$ Autoliths in Ph 2-3 $\mid$ Phase 2 $\mid \begin{array}{ll}\text { Phase 3 }\end{array}$

\begin{tabular}{cccccccccc}
$\begin{array}{c}\text { Mean } \\
\text { of 18 }\end{array}$ & $\begin{array}{c}\text { Std } \\
\text { Dev. }\end{array}$ & $\begin{array}{c}\text { Mean } \\
\text { of 3 }\end{array}$ & $\begin{array}{c}\text { Std } \\
\text { Dev. }\end{array}$ & $\begin{array}{c}\text { Mean } \\
\text { of 10 }\end{array}$ & $\begin{array}{c}\text { Std } \\
\text { Deviation }\end{array}$ & $\begin{array}{c}\text { Mean } \\
\text { of } 10\end{array}$ & $\begin{array}{c}\text { Std } \\
\text { Dev. }\end{array}$ & $\begin{array}{c}\text { Mean } \\
\text { of 9 }\end{array}$ & $\begin{array}{c}\text { Std } \\
\text { Dev. }\end{array}$ \\
\hline 33.04 & 1.48 & 32.93 & 1.09 & 30.51 & 2.82 & 35.25 & 2.02 & 33.57 & 1.58 \\
0.99 & 0.31 & 1.02 & 0.19 & 1.03 & 0.15 & 0.79 & 0.27 & 0.77 & 0.25 \\
1.78 & 0.28 & 2.14 & 0.10 & 2.02 & 0.35 & 2.76 & 0.51 & 1.88 & 0.42 \\
0.28 & 0.05 & 0.36 & 0.06 & 0.28 & 0.04 & 0.25 & 0.05 & 0.27 & 0.09 \\
2.50 & 0.55 & 2.52 & 0.33 & 2.93 & 0.49 & 2.68 & 0.26 & 2.66 & 0.71 \\
5.51 & 0.45 & 5.23 & 0.12 & 4.89 & 0.46 & 4.38 & 0.78 & 4.72 & 0.72 \\
0.16 & 0.02 & 0.19 & 0.02 & 0.17 & 0.03 & 0.13 & 0.03 & 0.14 & 0.02 \\
36.12 & 2.08 & 34.56 & 0.66 & 32.91 & 3.10 & 30.62 & 2.23 & 34.78 & 2.67 \\
6.79 & 2.02 & 7.78 & 0.84 & 9.46 & 3.34 & 6.56 & 2.10 & 6.64 & 2.22 \\
0.12 & 0.04 & 0.18 & 0.03 & 0.12 & 0.04 & 0.16 & 0.03 & 0.12 & 0.09 \\
0.16 & 0.09 & 0.31 & 0.09 & 0.14 & 0.04 & 0.62 & 0.19 & 0.22 & 0.20 \\
0.43 & 0.10 & 0.83 & 0.14 & 0.48 & 0.12 & 0.30 & 0.18 & 0.24 & 0.18 \\
4.75 & 1.76 & 5.17 & 0.51 & 6.96 & 2.58 & 4.40 & 1.56 & 5.03 & 1.55 \\
5.31 & 1.16 & 5.36 & 0.39 & 6.19 & 1.40 & 7.65 & 2.00 & 6.89 & 1.61 \\
0.88 & 0.57 & 0.68 & 0.13 & 1.11 & 0.77 & 2.05 & 1.06 & 1.01 & 0.40 \\
10.91 & 1.24 & 10.98 & 0.55 & 14.12 & 2.89 & 14.40 & 2.18 & 12.85 & 2.37 \\
\hline 99.41 & & 99.59 & & 99.60 & & 99.39 & & 99.38 &
\end{tabular}

$\mathrm{SiO}_{2}$

$\mathrm{TiO}_{2}$

$\mathrm{Al}_{2} \mathrm{O}_{3}$

$\mathrm{Cr}_{2} \mathrm{O}_{3}$

$\mathrm{Fe}_{2} \mathrm{O}_{3}$

$\mathrm{FeO}$

$\mathrm{MnO}$

$\mathrm{MgO}$

$\mathrm{CaO}$

$\mathrm{Na}_{2} \mathrm{O}$

$\mathrm{K}_{2} \mathrm{O}$

$\mathrm{P}_{2} \mathrm{O}_{5}$

$\mathrm{CO}_{2}$

$\mathrm{H}_{2} \mathrm{O}^{+}$

$\mathrm{H}_{2} \mathrm{O}^{-}$

LOI

Totals

1637

$\mathrm{Ba}, \mathrm{ppm}$

$1637 \quad 576 \quad 221$

$2210 \quad 142$

$\mathrm{Rb}, \mathrm{ppm}$

29

13

59

$142 \quad 1188$

$919 \quad 1173$

$\mathrm{Sr}, \mathrm{ppm}$

$577 \quad 226$

823

6

20

$143 \quad 32$

239

$\mathrm{Zr}, \mathrm{ppm}$

66

117

145

373

14

66

665

$1054 \quad 885$

$\mathrm{Y}, \mathrm{ppm}$

$\begin{array}{lll}7 & 2 & 12\end{array}$

40

110

274

413

105

21

34

36

$\mathrm{S}, \mathrm{wt} \%$

$\mathrm{Pb}, \mathrm{ppm}$

0.09

12
0.06

20
0

49

35

61

$171 \quad 326 \quad 270$

$\mathrm{Ni}, \mathrm{ppm}$

6

0.05

11

1383

111

11

0.01

6

0

5

8

0.12

40

$96 \quad 41$

$\mathrm{F}, \mathrm{ppm}$

557

181

1
126

4

857

126

936

3

6

$\begin{array}{lll}57 & 673 & 268\end{array}$

1315

23

Cont Index

0.962

$0.072 \quad 1.002$

$\begin{array}{cc}0.007 & 7.52 \\ 0.016 & 0.26 \\ 0.015 & 0.61 \\ 0.53 & 14.75\end{array}$

0.44
0.03
0.14
2.97

511

0.11

$\begin{array}{ll}6 & 3\end{array}$

Fe

0.458

0.030

0.242

0.187

0.53

14.75

2.97

$\begin{array}{cccc}1.203 & 0.085 & 1.014 & 0.060 \\ 0.240 & 0.043 & 0.224 & 0.024 \\ 0.622 & 0.082 & 0.592 & 0.255 \\ 14.40 & 2.05 & 13.17 & 2.27\end{array}$

Mineral modes in kimberlite groundmass and matrices by SEM image analysis

\begin{tabular}{|c|c|c|}
\hline & Phase 1 & Ph 1 Chilled Margin \\
\hline Serpentine & $46-65$ & $46-59$ \\
\hline Ol microphenocryst & $9-12$ & $10-22$ \\
\hline Calcite, primary & $18-36$ & $21-24$ \\
\hline Apatite & $0-2$ & $5-7$ \\
\hline Phlogopite & $0-1$ & 2 \\
\hline Spl+Ilm+Per & $2-5$ & $3-6$ \\
\hline \multicolumn{3}{|c|}{ Carbonate, late (magnesite to calcite) } \\
\hline \multicolumn{3}{|c|}{ Late mixed-layer $\mathrm{Mg}$-rich } \\
\hline
\end{tabular}

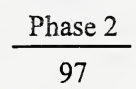

Phase 3

$55-60$

Serpentine

46-65

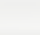$$
\text { 5-7 }
$$$$
\text { 3-6 }
$$$$
3
$$

may also be present

5
$11-20$ 